\title{
Working From Home Policy For Indonesian Civil Servants During Coronavirus Disease Pandemic
}

\section{Kebijakan Bekerja Dari Rumah Bagi Pegawai Negeri Sipil Selama Masa Pandemi Virus Corona}

\author{
Rochmat Ali Syaefudin \\ Ministry of Health Republik of Indonesia \\ email: rochmatalis@gmail.com
}

\begin{abstract}
World Health Organization (WHO) has declared Coronavirus disease (COVID-19) as A global pandemic. According to 2019 data from the National Civil Service Agency (BKN), Indonesia has more than 4.28 million civil servants across the country. President joko Widodo has urged everyone to stay at home, (including civil servants) and work from home. Working from home for Indonesian civil servants is a new practice. THERE has been NO Government Regulations THAT regulates work from home policy before. Work from home policy implemented during COVID-19 pandemic in a bid TO prevent THE SPREAD OF THE VIRUS. Technology and qualified civil servants need to maintain public services from home. Regulations and StandarD Operational Procedures (SOP) of work from home policy need to ensure THAT public interests and services ARE not interrupted during THE pandemic period.
\end{abstract}

Keywords: civil servant; covid-19; pandemic; policy; work from home

\begin{abstract}
Abstrak
Organisasi Kesehatan Dunia (WHO) telah menyatakan sebagai pandemi. Menurut data Badan Kepegawaian Negara tahun 2019, terdapat 4.28 juta orang Pegawai Negeri Sipil yang tersebar di seluruh Indonesia. Presiden Joko Widodo menghimbau semua orang untuk tetap di rumah (termasuk Pegawai Negeri Sipil) dan bekerja dari rumah selama masa pandemi. Bagi Pegawai Negeri Sipil, bekerja dari rumah dalam praktik baru. Sebelumnya, tidak ada peraturan perundang-undangan yang mengatur mengenai kebijakan bekerja dari rumah. Kebijakan bekerja dari rumah diterapkan selama masa pandemi COVID-19 sebagai usaha menghambat penyebaran virus. Peraturan dan Standar Operasional Prosedur (SOP) tentang kebijakan bekerja dari rumah diperlukan untuk memastikan pelayanan publik tidak terganggu selama masa pandemi.
\end{abstract}

Kata kunci: bekerja dari rumah; covid-19; kebijakan; pns; pandemi 


\section{Introduction}

World Health Organization (WHO) has declared Coronavirus disease (COVID-19) as a global pandemic. Indonesia reported first death of COVID-19 cases on March 12, 2020. Approximately, more than four hundred confirmed cases with at least hundred deaths a month later due to covid-19 (Ministry of Health, 2020). Several advices were given to prevent the spread of coronavirus, washing hand and social (or physical) distancing is the most common advice.

President Joko Widodo speech has urged everyone to stay at home (including civil servants) and work from home. He also highlighted the importance of practicing social distancing (Cahya, 2020). Government has set up a fast response team led by National Disaster Mitigation Agency (BNPB) called Gugus Tugas Penanggulangan COVID-19.

In Hong Kong, civil servants have been working from home since late January 2020 in a bid to stop the spread of the deadly virus. Government has closed their offices except emergency, essential and basic public services. The city's public sports facilities, museums, and libraries have been shut until further notice (Lee \& Lum, 2020).

There is no study about working from home policy for Indonesia civil servants before, especially during outbreak or disaster. Only conducted about problems and actors which can be applied by teleworking for Indonesian civil servants (Suarlan, 2017). This paper will discuss the implementation of working from home policy for Indonesian civil servants during COVID19 global pandemic.

Many organizations are considering adopting homeworking policies, but there are some uncertainty as to how to proceed and a lack of agreed guidelines (Dwelly \& Bennion, 2003). This research conducted by looking at the regulations, documents, news, and data about working from home policy for Indonesian civil servants during COVID-19 pandemic and how the policies are being implemented.

\section{Methods}

According to 2019 data from the National Civil Service Agency (BKN), Indonesia has more than 4.28 million civil servants across the country. During COVID-19 pandemic, The Indonesian Administrative and Bureaucratic Reform Ministry (MENPAN-RB) has allowed civil servants to work-from-home to prevent the spread of the coronavirus (Cahya, 2020).

Working from home in Indonesia is not something new. It has been applied by startup technology industries company. Computer engineer such as software programmer and graphic designer can do their job from home, café, or co working spaces. 
Tabel 1.

Civil servants growth chart

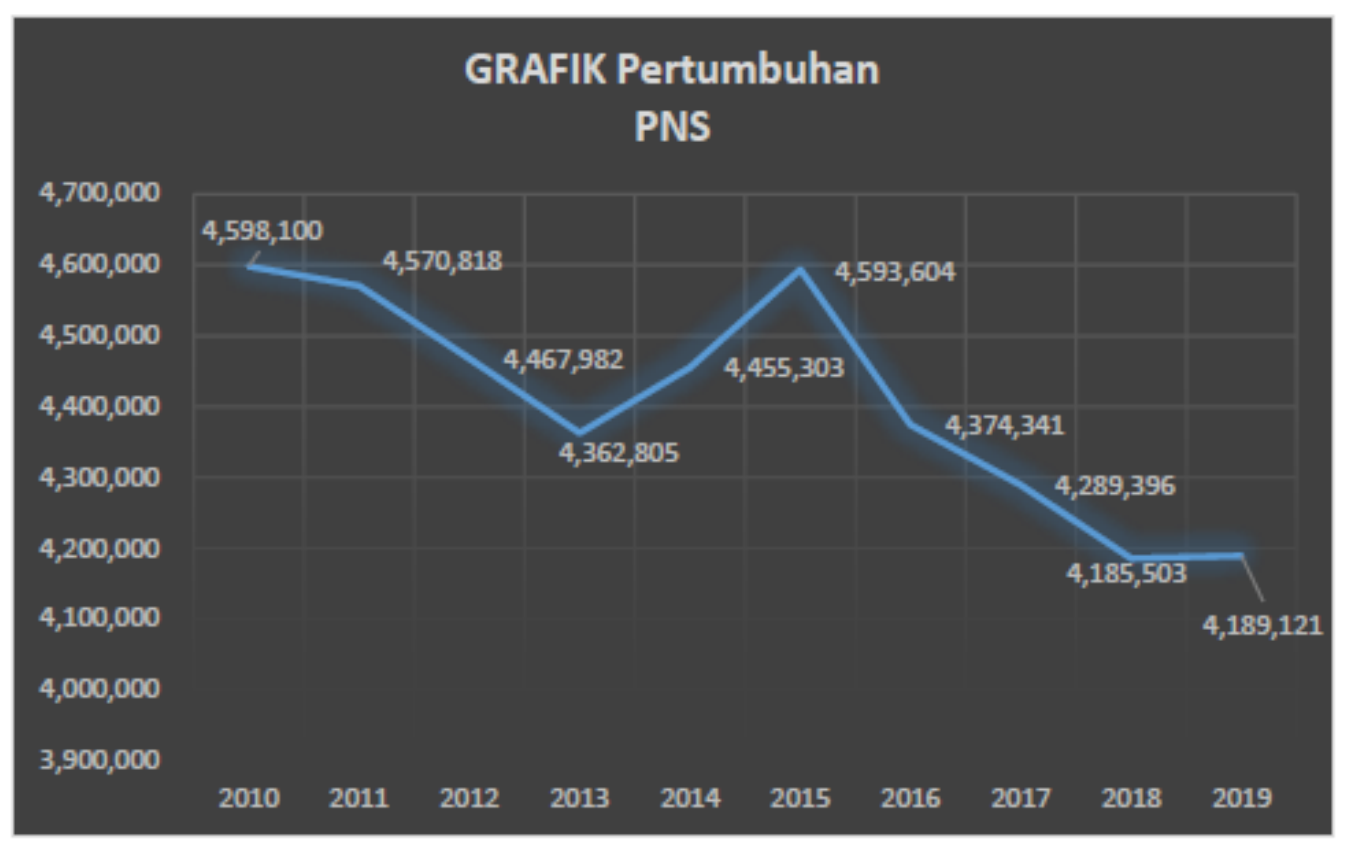

Source: National Civil Service Agency, 2019

Sometimes civil servants work outside office for couple of days, usually in hotel, but not in home. State Civil Apparatus Act No. 5/2014 and Government Regulations of Civil Servants Management No. 11/2017 juncto No. 33/2019 doesn't implicit the regulations of working from home for civil servants. The Indonesian Administrative and Bureaucratic Reform Ministry (MENPAN-RB) has planned to implement a flexible working regiment in six agencies on January 2019, but it is not a full work from home policy (Taher, 2019). Working from home means that paid-work is done mainly from home and provide flexible time for workers (Crosbie \& Moore, 2004)

After the first COVID-19 case announcement, The Indonesian Administrative and Bureaucratic Reform Ministry (MENPAN-RB) issued a Minister Circular Letter No. 19/2020 on March 16, 2020. It regulates the adjustment of civil servant's work system in preventing the spread of coronavirus in government agencies, including working from home policy for civil servants.

According to the letter, there are only two level of higher management that should stay working in office. First, work from home system applied by filtering civil servants from their home location, health record, travel history in the last 14 days, and their job description.

The Indonesian Administrative and Bureaucratic Reform Ministry (MENPAN-RB) issued another regulation on March 30, 2020 due to the pandemic spreadness. The Minister Circular Letter No. 34/2020 revises previous Circular Letter No. 19/2020. It added important point e.g. work from home period for Indonesia civil servants was extended to April 2l, 2020. 
Every head agencies should consider the region status due to the coronavirus spreadness before applying work from home. Several regions, such as capital city of Jakarta and West Java Province has implemented large-scale of social restriction. Civil servants who violate the policy, and could not reach work from home's target, is threatened with disciplinary sanctions.

Work from home period WAS extended until May 13, 2020 with The Minister Circular Letter No. 50/2020. Civil servants also recommended to use smartphone application called Peduli Lindungi provide by Ministry of Communication and Informatics for government health surveillance necessity support.

In addition to prevent the virus from spreading, government banned civil servants, soldiers, and police from going on the annual moslem homecoming tradition (mudik). Every year, more than four million people leave urban centers to return to their hometown to celebrate eid al-fitr. In 2019, 33 million Indonesians left big cities during mudik to small towns and villages around the country (Tambun et al., 2020).

Leave allowance is restricted. Leave due to emergency, will only be allowed with permission from civil servants superior. THE Same principle applies to civil servants leave. Permissions will only be given for maternity leave, sick leave, and leave due to important reasons, such as an illness or death in the main family.

Working at home includes not only telecommuting, but also bringing work home to finish after business hours (Song \& Gao, 2018). Technology has had a significant impact on work, making work from home and other locations possible (Farrell, 2017). The purpose of Working from home during COVID-19 pandemic for Indonesian civil servant is to implement social and physical distancing to reduce coronavirus spreadness. IT IS believed THAT CORONAVIRUS CAN spread via droplet or cough, THEREFORE physical distancing is important to prevent THE SPREADNESS OF THE VIRUS. Working from home is believed to be effective in applying social (or physical) distancing advice.

Indonesia civil servants consist a large number of professions. Civil servants in government hospital and other health facilities have to work with normal system. Doctor, nurse, and other health personnel took vital role during the pandemic. Shift work system in normal condition can't be applied during coronavirus pandemic. Civil servants in health facilities have to work with long working hours.

Knowledge of Information technology would be a mandatory for civil servants quality in the future (Effendi, 2020). During work from home period, face-to-face officials meeting is banned. Civil servants are obliged to use teleconferences or video calls for officials meeting from home. Several public services application can be operated online from home, mostly administrative task.

Domestic and abroad business trip is also banned. Civil servants who had abroad business trip that shows fever and cough symptoms had to do self-quarantine and contact Ministry of Health hotline number.

Every agency head is still needed to assign a few officials at each office to maintain its public service obligation. People entering all government offices and buildings with public access would get a body temperature check. Some services would only be offered on alternate days or after pandemic. Every agency is also sterilized with disinfectant. 
Civil servants must stay at home and must not leave except for urgent matters such as buying groceries or going to the hospital. They have to report such activities to their superiors immediately.

Civil servants who works in capital city of Jakarta takes public transportation such as bus, train, and online based ojek (motorcycle taxi) from their home in Bogor, Depok, Tangerang, and Bekasi, near the capital city. The implementation of Large-scale social restriction (PSBB) in Jakarta restricts civil servants access to public transportation.

Large-scale social restriction implementations (PSBB) is also applied in several other cities such as Bandung, Makassar, and Surabaya. Mainly civil servants in large-scale social restriction implementations area are working full from home.

Face-to-face meeting is also banned during the pandemic. Civil servants are obliged to attend teleconferences or video calls for officials meeting. They are forced to use third party online meeting applications such as Zoom before the Ministry of Communication and Informations introduces similar application, CloudX.

All civil servants still have the right to receive salary and monthly performance allowances. Meal allowance is also paid as usual as working in office. During work from home period, civil servants are advised to avoid social and meal gatherings.

Teacher and lecturer is using internet to teach during work from home period. Politeknik Kesehatan Kementerian Kesehatan Surakarta (Health Polytechnic of Surakarta), a health academy supervised by Ministry of Health applied work from home policy and dismissed their students from lectures in class since March 16, 2020.

Combination of e-learning and video conferences is used to replace the traditional classroom. Examination has to be held online. Several applications are used by civil servants in education sector, such as Google Classroom, Zoom, and Schoology.

Human resources has an important role to ensure teleworking and prepared work in home environment (Basile \& Beauregard, 2016). The Indonesian Administrative and Bureaucratic Reform Ministry (MENPAN-RB) and National Civil Service Agency (BKN) plays important rules in implementing work from home policy.

Ministry of Communication and Informations also has to guarantee the availability of data security transfer during work from home. Online applications have to be prepared to support working from home policy. Official data that has been processed by civil servants from home should be sent in encryption to agencies. It aims to minimize the leaking of important government information that impacts the public.

\section{Results and Discussion}

Work from home policy for Indonesian civil servants gives new experience for government and civil servants itself. There are several improvements needed for work from home policy for Indonesia civil servants.

First of all is by supporting the policy regulation. Constitution (undang-undang), government regulations (peraturan pemerintah), and standard operational procedure (SOP) has to be available. This regulation should regulates reason of the policy, implementation procedure, allowances, internet cost, and overtime cost. 
Second is human resources. Government should increase the civil servant's ability of using information technology. This includes how to use computer, internet, electronic mail, data transfer, and government software or application. Reducing civil servants who lacks in computer skill can be a support for government reformation on improving public services.

Safe network for transferring government data during the work from home policy is also important. Furthermore, government should consider to reduce the working hours during work from home period to decrease civil servants from risk of stress and boredom. 


\section{References}

Basile, K. A., \& Beauregard, T. A. (2016). Strategies for successful telework: how effective employees manage work/home boundaries. Strategic HR Review, 15(3), 106-111. https://doi.org/10.1108/shr-03-2016-0024

Cahya, G. H. (2020). Stay home, President says. The Jakarta Post. https://www.thejakartapost.com/news/2020/03/16/stay-home-president-says.html

Crosbie, T., \& Moore, J. (2004). Work-life Balance and Working from Home. Social Policy and Society, 3(3), 223-233. https://doi.org/10.1017/s1474746404001733

Dwelly, T., \& Bennion, Y. (2003). Time to go home: Embracing the homeworking revolution. http://www.timdwelly.com/portfolio/Time to go home.pdf

Effendi. (2020). Mungkinkah Aparatur Sipil Negara (ASN) Bekerja Di

Rumah? Jurnal Social Society. http://www.jurnalsocialsecurity.com/jurnal/mungkinkanaparatur-sipil-negara-asn-bekerja-di-rumah.html

Farrell, K. (2017). Working from home: A double edged sword. 0-26.

Lee, D., \& Lum, A. (2020). Coronavirus: Hong Kong civil servants set to return to offices from next Monday as work-from-home arrangements come to an end. South China Morning Post. https://www.scmp.com/news/hong-kong/healthenvironment/article/3052335/coronavirus-hong-kong-civil-servants-set-return

Song, Y., \& Gao, J. (2018). Does Telework Stress Employees Out? A Study on Working at Home and Subjective Well-Being for Wage/Salary Workers. IZA DP, 11993.

Suarlan. (2017). Teleworking for Indonesian Civil Servants : Problems and Actors. 24(2), 100-109.

Taher, A. P. (2019). KemenpanRB Sebut Tidak Semua ASN Bisa Kerja di

Rumah. Tirto. https://tirto.id/kemenpanrb-sebut-tidak-semua-asn-bisa-kerja-di-rumahemL4

Tambun, L. T., Lumanauw, N., \& Putuhena, I. M. (2020). Jokowi Bans Mudik as Police Prepare to Close Off Roads In and Out of Jakarta. The Jakarta Globe. https://jakartaglobe.id/news/jokowi-bans-mudik-as-police-prepare-to-close-off-roads-inand-out-of-jakarta/ 